Vol. 7 (1998): 447-453.

\title{
Salt content labelling of foods in supermarkets in Finland
}

\author{
Maria Närhinen \\ Department of Public Health and General Practice, University of Kuopio, Finland. Current address: \\ Mikkeli Joint Municipal Board for Public Health, PO Box 167, FIN-50101 Mikkeli, Finland, \\ e-mail: NARHIMA\%MKT10.DNET@HELO2.KTT.FI
}

Aulikki Nissinen

Department of Public Health and General Practice, University of Kuopio, PO Box 1627, FIN-70211 Kuopio, Finland

Pirjo-Liisa Penttilä

National Food Administration, PO Box 5, FIN-00531 Helsinki, Finland

Olli Simonen

Department for Prevention and Promotion, The Ministry of Social Affairs and Health, PO Box 197, FIN-00531 Helsinki, Finland

Lars Cernerud

University College of Health Sciences, PO Box 1038, S-55111 Jönköping, Sweden

Pekka Puska

Department of Epidemiology and Health Promotion, National Public Health Institute, Mannerheimintie 166, FIN-00300 Helsinki, Finland

\begin{abstract}
The aim of the study was to assess the extent to which lightly salted food products are included in the assortments of Finnish supermarkets and prominently placed on shelves. The study was carried out in eastern Finland in four supermarkets of different food chains. Six food groups of importance for people's salt intake were considered. The food labels of 689 packaged food products were checked for salt and sodium information on the basis of Finnish regulations on salt. Products with reduced salt contents were found in most food groups but not among whole-meat or ready-to-eat foods. Half of the products with reduced amounts of salt were labelled "lightly salted". All four supermarkets had a similar assortment of lightly salted products. From the public health point of view, the food industry should increase the supply of lightly salted products, and make a special effort to develop lightly salted ready-to-eat foods.
\end{abstract}

Key words: dietary salt, food labelling, sodium, supermarkets

(C) Agricultural and Food Science in Finland

Manuscript received October 1998 
Närhinen, M. et al. Salt labelling in supermarkets

\section{Introduction}

The main dietary problem in developed countries is an excess intake of fat, especially saturated fat, and of salt $(\mathrm{NaCl})$ and too low an intake of dietary fibre, fruits and vegetables (WHO 1988 and 1990). In the 1970s, when the Finnish diet was very high in saturated fat (21\% of energy) and low in vegetables (Pietinen et al. 1996), Finland had the highest coronary heart disease mortality in the world (Puska et al. 1995). Salt intake was also high the daily intake being $14 \mathrm{~g}$ among men and $11 \mathrm{~g}$ among women (Pietinen et al. 1996). In 1979, a community-based programme to reduce salt consumption was launched in the province of North Karelia as part of the North Karelia Project (Pietinen et al. 1996). The aim of the programme, planned to run for 3 years, was to evaluate the feasibility and effects of reducing salt intake in the whole population. The strategies included both health education and environmental modification.

The National Public Health Institute has monitored the dietary habits of the Finnish population at 5-years intervals since 1972. The 1992 dietary survey (Kleemola et al. 1994) showed that salt intake had declined throughout the country and was about the same in all areas, $12 \mathrm{~g}$ among men and 8-9 $\mathrm{g}$ among women. This amount, however, clearly exceeds the latest nutrition recommendations, (Nordic Nutrition Recommendations 1996), which state that the intake of sodium should be reduced to an amount corresponding to $5 \mathrm{~g}$ salt per day. The Nordic Recommendations for salt intake are in concordance with the nutrient goals set by WHO (WHO 1990).

The main sources of dietary salt in Finland are meat products, bread, dairy products (fats and cheese) and salt used in households (National Public Health Institute 1996). The problem of excess salt intake has been recognised in the Finnish food legislation and several decrees have been issued on salt (Pietinen et al. 1996). If the salt content is above a certain level products must be labelled as "heavily salted"; if, however, the salt content is under a given limit products can be labelled as having "reduced salt content"
(= "lightly salted"). The salt content must also be given on most packed foods that are important for the population's intake of salt. Finland thus follows a stricter strategy in salt labelling than do most other countries (Närhinen and Cernerud 1995). After Finland became a member of the European Union, its food legislation was harmonized with that of the EU, a move leading to some changes in salt legislation. In view, however, of the continuing high rates of hypertension and cardiovascular disease in Finland the regulations about mandatory labelling of salt content and "heavily salted" as well as the voluntary labelling of "reduced salt content" were not amended. The sodium content is given as part of the nutritional information on the label. Although voluntary for most products, nutritional labelling becomes mandatory as soon as any nutritional claims are made for a product.

In response to the growing health consciousness of its customers, the Finnish food industry has been active in developing new products. Moreover, the lower limits for "heavily salted" products introduced in 1992 have led to reduction in the salt content of certain foods, e.g. bread and sausages to avoid having to label them as "heavily salted" (Pietinen et al. 1996). Still, if we are to reach the nutrition goal of no more than $5 \mathrm{~g}$ salt per day the availability of products fulfilling the criteria for "reduced salt content" has to be further improved. Studies have shown that "in store decisions" account for nearly two thirds of all purchases in supermarkets (Light et al. 1989). It thus seems reasonable to assume that information on salt content is of importance in food choices made by customers. This study sought to establish to what extent lightly salted products were included in the assortments of supermarkets and, if they were, how prominently they were placed on shelves.

\section{Material and methods}

The study was carried out by the cross-sectional observational method in two Finnish towns 
Vol. 7 (1998): 447-453.

Table 1. Finnish food legislation on limits for voluntary labelling as "lightly salted" and obligatory labelling as "heavily salted" for foods included in the survey. Number of food items found in different groups.

\begin{tabular}{|c|c|c|c|c|}
\hline Group & Assortment & $\begin{array}{l}\text { Limit for lightly } \\
\text { salted } \\
\mathrm{NaCl} g / 100 \mathrm{~g} *)\end{array}$ & $\begin{array}{l}\text { Limit for heavily } \\
\text { salted } \\
\mathrm{NaCl} \mathrm{g} / 100 \mathrm{~g}\end{array}$ & $\mathrm{~N}$ \\
\hline Fats & Whole group & 1.0 & 2.0 & 53 \\
\hline Cheeses & Hard cheese, cheese spread & 0.7 & 1.4 & 117 \\
\hline Cooked sausages & Whole group & 1.2 & 1.8 & 68 \\
\hline Whole meat products & Whole group & 1.2 & $-* *)$ & 48 \\
\hline Ready to eat foods & $\begin{array}{l}\text { Casserole, pizza, } \\
\text { hamburger products }\end{array}$ & 0.5 & $-* *)$ & 74 \\
\hline Fresh bread & Whole group & 0.7 & 1.3 & 107 \\
\hline Crispbreads & Whole group & 1.2 & 1.7 & 52 \\
\hline Bouillon concentrate & Cubes & $\left.0.5^{* * *}\right)$ & $-* *)$ & 36 \\
\hline Spice mixtures & Whole group & ****) & $-* *)$ & 134 \\
\hline Total & & & & 689 \\
\hline
\end{tabular}

*) 1 gram $\mathrm{Na}=2,5$ gram $\mathrm{NaCl}$

**) No limit for heavily salted given

***) Content in prepared bouillon

****) No limit for lightly salted given

Mikkeli and Pieksämäki, in eastern Finland. Mikkeli, the provincial capital, has 33000 inhabitants and Pieksämäki, situated $100 \mathrm{~km}$ north of Mikkeli, 14000 inhabitants. About 70-75\% of the work force in both towns is in service jobs.

The concentration of the grocer's retail trade is high in Finland; about $94 \%$ of grocery sales in Finland was controlled by central whole sale companies in 1995 (Raijas 1997). The survey was carried out in four supermarkets, three of them in Mikkeli. All belonged to different food chains ranging in size from $1000 \mathrm{~m}^{2}$ to $6200 \mathrm{~m}^{2}$ and represented the largest shops in each chain. Thus all Finland's major food chains were included in the study. Shops were surveyed on 16 November - 10 December 1995 and 2 January 1996 - 1 February 1996. The food groups selected, based on knowledge of the most important sources of salt and fat in Finland (National Public Health Institute 1996), were dairy products (fats and cheese), meat products, ready-toeat foods, bouillon concentrate and bread. Spice mixtures were included because many mixtures of salt and spices are available and are promoted as an alternative to salt. They therefore re- flect the use of salt in home cooking. The survey covered all food items in the above groups packed and labelled by the food industry, but not those packed in the supermarket.

The same person, a food control official (Närhinen) collected the data in all the shops. The supermarkets were not informed about the survey until the data collection started. The ingredients and the nutrition information on labels were checked on all the selected products. All food shelves were checked to see if lightly salted products were grouped together or if there were any signs that might guide customers to look for foods containing less salt. All food items were checked only once. If a product was found in more than one supermarket, as many were, the label was checked only in the first shop.

The existing Finnish regulations on salt labelling were used as a reference and products were grouped as lightly or heavily salted according to the Finnish reference limits (Table 1).

The variables in the analyses were either dichotomous, indicating whether or not a package had a salt label or continuous, indicating the salt content of the food item. 
Närhinen, M. et al. Salt labelling in supermarkets

Table 2. Proportion of products with salt and sodium labelling as percentages of products checked. Mean labelled salt content and distribution of lightly salted, normally salted and heavily salted foods in different food groups. Classification as lightly, normally or heavily salted according to Finnish food legislation.

\begin{tabular}{|c|c|c|c|c|c|c|}
\hline \multirow[t]{2}{*}{ Group } & \multicolumn{2}{|c|}{ Labelled products } & \multirow{2}{*}{$\begin{array}{l}\text { Labelled salt } \\
\text { in } \mathrm{g} / 100 \mathrm{~g} \\
\text { Mean } \pm \mathrm{SD}\end{array}$} & \multirow{2}{*}{$\begin{array}{c}\text { Lightly } \\
\text { salted } \\
\%\end{array}$} & \multirow{2}{*}{$\begin{array}{c}\text { Normally } \\
\text { salted } \\
\% \\
\%\end{array}$} & \multirow{2}{*}{$\begin{array}{c}\text { Heavily } \\
\text { salted } \\
\% \\
\%\end{array}$} \\
\hline & $\begin{array}{c}\mathrm{NaCl} \\
\% \\
\end{array}$ & $\begin{array}{c}\mathrm{Na} \\
\%\end{array}$ & & & & \\
\hline Fats & 93.9 & 18.8 & $1.3 \pm 0.4$ & 23.9 & 69.6 & 6.5 \\
\hline Cheeses & 94.0 & 1.7 & $1.3 \pm 0.5$ & 12.8 & 59.6 & 27.5 \\
\hline Cooked sausages & 100 & 12.1 & $1.7 \pm 0.2$ & 10.3 & 83.8 & 5.9 \\
\hline Whole meat products & 95.8 & 0 & $2.3 \pm 0.6$ & 0 & 100 & $-*)$ \\
\hline Ready to eat foods & 95.9 & 23.3 & $1.1 \pm 0.3$ & 0 & 100 & $-*)$ \\
\hline Fresh bread & 99.1 & 21.5 & $1.2 \pm 0.2$ & 6.6 & 92.5 & 0. \\
\hline Crispbreads & 94.2 & 35.3 & $1.4 \pm 0.4$ & 38.8 & 51.0 & 10. \\
\hline Bouillon concentrate & 97.2 & 14.7 & $0.9 \pm 0.2$ & 11.4 & 88.6 & $-*)$ \\
\hline Spice mixtures & $98.0 * *)$ & 1.0 & $\left.42.9 \pm 22.0^{* *}\right)$ & $\left.23.9^{* * *}\right)$ & $76.1 * * * *)$ & $-*)$ \\
\hline
\end{tabular}

*) No limit given for extra salted in Finnish food legislation

**) Spice mixtures with salt as an ingredient

***) Proportion of spice mixtures without salt

****) Proportion of spice mixtures with salt as an ingredient

\section{Results}

The food labels of 689 packaged food products, $74 \%$ of them made in Finland, were checked. Salt labelling $(\mathrm{NaCl})$ was available on the majority. Overall, salt labelling was much more common than was information on the sodium content. The frequencies of salt labelling and the labelled salt contents of the products are given in Table 2 . The products were classified as lightly salted, normally salted or heavily salted as required by Finnish food legislation. Lightly salted foods were found in all groups with the exception of ready-to-eat and whole-meat products; they were most common among crispbreads and fats. Heavily salted products were rare with the exception of cheeses; a quarter of which were heavily salted. The mean salt percentage of sausages was considerably lower than that of whole meat-products, for which there is no limit above which they have to be labelled as heavily salted. The mean salt content of salt-spice mixtures was high, being on average $43 \%$. The majority of the heavily salted cheeses were of foreign origin as were, in contrast, most of the lightly salted crisp breads.

Table 3 shows the proportion of lightly salted products in the assortments of four supermarkets. In supermarket 1, the largest of the four, the proportion of lightly salted sausages was smaller than that in the other supermarkets. Supermarket 4 , the smallest of the four, had no lightly salted bouillon concentrate. Otherwise the proportions of lightly salted products in the shops were very similar.

All supermarkets placed the lightly salted products among the standard products; none of them grouped lightly salted products together or displayed any signs making it easier for customers to find the products. Table 4 summarises the total number of products found that satisfied the criteria for lightly salted. Only about half of these products were in fact labelled as "lightly salted". 
Vol. 7 (1998): 447-453.

Table 3. Proportion of products with reduced salt content in the different food groups in the four supermarkets.

\begin{tabular}{lcccc}
\hline Group & $\begin{array}{c}\text { Supermarket 1 } \\
\%\end{array}$ & $\begin{array}{c}\text { Supermarket 2 } \\
\%\end{array}$ & $\begin{array}{c}\text { Supermarket 3 } \\
\%\end{array}$ & $\begin{array}{c}\text { Supermarket 4 } \\
\%\end{array}$ \\
\hline Fats & 26.5 & 26.5 & 37.5 & 26.7 \\
Cheeses & 12.5 & 13.8 & 12.0 & 9.5 \\
Cooked sausages & 4.4 & 14.6 & 12.0 & 11.8 \\
Whole meat products & 0 & 0 & 0 & 0 \\
Ready to eat foods & 0 & 0 & 0 & 0 \\
Bread & 20.4 & 21.2 & 19.7 & 24.0 \\
Bouillon concentrate & 15.8 & 8.7 & 6.3 & 0 \\
Spice mixtures*) & 31.7 & 16.7 & 16.2 & 23.3 \\
\hline
\end{tabular}

*) Proportion of spice mixtures without salt

\section{Discussion}

The latest nutrition recommendation, that salt intake should not exceed $5 \mathrm{~g}$ salt per day (Nordic Nutrition recommendations 1996), calls for a further reduction in salt consumption. One way in which consumers could cut their salt intake would be by choosing lightly salted products in supermarkets whenever possible. In the four supermarkets surveyed here, lightly salted products were available in most food groups, thus enabling customers to make such a choice. There were, however, no lightly salted whole-meat or ready-to-eat foods. As consumers are purchasing ready-to-eat foods in increasing amounts, the absence of lightly salted varieties was a disturbing finding. To accustom children to a low-salt diet from the start, it would be particularly important to expand the range of lightly salted ready-to-eat foods targeted at young families. Today the salt intake of children in Finland exceeds the Nordic recommendations more than twofold (Kallio et al. 1998).

As the lightly salted products accounted for only a small fraction of the assortment of some foods it is possible that customers will not find them very easily. Had they been grouped together, they would have been more visible. The food industry could also enhance the visibility of lightly salted products by making greater use of the voluntary "lightly salted" label. In one of the shops surveyed all cheeses with a fat content of $17 \%$ or less were grouped together under a sign saying "Light cheese" ( = reduced fat). According to the manager, customers were pleased with this arrangement. Placing lightly salted products together might generate a similar favourable response.

Salt labelling was much more common than was labelling about sodium content. All in all the food industry seems to be complying well with regulations on salt. Thus, it seems appropriate that Finland should continue to use salt rather than sodium in its regulations, even though sodium is the harmful ingredient in salt.

Table 4. Proportion of foods satisfying the criteria for reduced salt content and labelled "lightly salted".

\begin{tabular}{lcc}
\hline Group & $\begin{array}{c}\text { Total number } \\
\text { of products with } \\
\text { reduced salt content } \\
\text { N }\end{array}$ & $\begin{array}{c}\text { Proportion } \\
\text { labelled with } \\
\text { "Lightly salted" } \\
\%\end{array}$ \\
\hline Fats & 11 & 63.6 \\
Cheeses & 14 & 42.9 \\
Cooked sausages & 7 & 57.1 \\
Fresh bread & 7 & 57.1 \\
Crispbreads & 19 & 52.6 \\
Bouillon concentrate & 4 & 100 \\
\hline
\end{tabular}


Närhinen, M. et al. Salt labelling in supermarkets

All shops surveyed were in the same region. Fresh bread was the only item produced locally; most of the other foods were produced by firms that distribute their products all over Finland. We can therefore reasonably assume that the situation regarding food labelling is much the same elsewhere in Finland too, although the assortments may differ from those found here. It would be interesting to find out if there are differences in the assortments between different areas. Cardiovascular disease is most common in eastern Finland and, according to the Health Behaviour Monitoring Survey among the Finnish Adult Population, made annually by the National Public Health Institute (KTL), there are differences in health behaviour between the east and west of Finland (Helakorpi et al. 1997). These differences may be reflected in the assortments of supermarkets in different regions. This is an issue for further research.
The prime challenge facing the food industry is to increase the supply of lightly salted products, and in particular to develop lightly salted ready-to-eat foods. Increasing the availability of lightly salted alternatives to many packaged foods provide consumers with the food choices they need to control their salt intake without greatly changing their eating habits. Another strategy would be to gradually reduce the salt content in existing products (Engstrom et al. 1997). The salt content of many foods has been reduced during the last 10 years (Pietinen 1996) but not far enough, as was pointed out at the Finnish National Heart Health Consensus Conference in 1997 (Consensus conference 1998).

Acknowledgements. This work was supported by the Finnish Veterinary Foundation.

\section{References}

Consensus conference on promoting heart health in Finland 1998. Action Plan for Promoting Heart Health in Finland. Publications of the Ministry of Social Affairs and Health. 12/1998. Helsinki.

Engstrom, A., Tobelman, R.C. \& Albertson, A.M. 1997. Sodium intake trends and food choices. American Journal of Clinical Nutrition 65: 704S-707S.

Helakorpi, S., Uutela, A., Prättälä, R., Berg, M.-A. \& Puska, P. 1997. Health Behaviour among Finnish Adult Population, Spring 1997. Publications of the National Public Health Institute B10/1997. Helsinki.

Kallio, K., Jokinen, E., Puotsaari, T. \& al. 1998. Pikkulasten suolan saanti. Suomen lääkärilehti 53: 13-17.

Kleemola, P., Virtanen, M. \& Pietinen, P. 1994. The 1992 Dietary Survey of Finnish Adults. Publications of the National Public Health Institute. B2/1994. Helsinki.

Light, L., Portnoy, B., Blair, J.E. \& al. 1989. Nutrition education in supermarkets. Family and Community Health 12: 43-52.

National Public Health Institute 1996. Nutritional report 1995. Publication of the National Public Health Institute B1/1996. Helsinki.

Nordic Nutrition Recommendations 1996. Scandinavian Journal of Nutrition 40: 161-165.
Närhinen, M. \& Cernerud, L. 1995. Salt and public health - policies for dietary salt in the Nordic countries. Scandinavian Journal of Primary Health Care 13: 300-306.

Pietinen, P., Vartiainen, E., Seppänen, R., Aro, A. \& Puska, P. 1996. Changes in Diet in Finland from 1972 to 1992 : Impact on Coronary Heart Disease Risk. Preventive Medicine 25: 243-250.

Puska, P., Tuomilehto, J., Nissinen, A. \& Vartiainen, E. (editors) 1995. The North Karelia Project 20 Year Results and Experiences. National Public Health Institute. Helsinki.

Raijas A. 1997. The consumer's choice of grocer's shop - a comparison between Two Metropolitan Areas in Finland and Norway. Publication of the National Consumer Research Centre 6/1997. Helsinki.

WHO 1988. Healthy nutrition. Preventing nutrition-related diseases in Europe. WHO Regional Publications, European Series, No. 24. Copenhagen.

- 1990. Diet, nutrition and the prevention of chronic diseases. WHO Technical Report Series. 797. Geneva. 
Vol. 7 (1998): 447-453.

\title{
SELOSTUS
}

\section{Suolamerkinnät valintamyymälöiden pakatuissa elintarvikkeissa}

\author{
Maria Närhinen, Aulikki Nissinen, Pirjo-Liisa Penttilä, Olli Simonen, Lars Cernerud ja Pekka Puska \\ Kuopion yliopisto, Elintarvikevirasto, Sosiaali- ja terveysministeriö, University College of \\ Health Sciences, Jönköping, Ruotsi ja Kansanterveyslaitos
}

Tutkimuksen tarkoituksena oli selvittää kuinka paljon vähäsuolaisia tuotteita löytyy suurten suomalaisten valintamyymälöiden valikoimista sekä miten nämä tuotteet ovat esillä kauppojen hyllyissä. Tutkimus tehtiin neljässä valintamyymälässä Mikkelin ja Pieksämäen seudulla. Myymälät valittiin edustamaan neljää eri kauppaketjua ja kunkin ketjun suurin myymälä otettiin mukaan tutkimukseen. Tutkimuksessa tarkasteltiin kuutta elintarvikeryhmää, joilla kaikilla on merkitystä suomalaisten suolan saannin kannalta. Kaikkiaan 689 valmiiksi pakatun elintarvikkeen myyntipäällyksestä kerättiin kaikki suolaa ja natriumia koskevat merkinnät. Lähtökohtana oli suoma- lainen elintarvikelainsäädäntö suolan ja natriumin merkitsemisestä myyntipäällyksiin. Vähäsuolaisia tuotteita löytyi suurimmasta osasta elintarvikeryhmiä, mutta vähäsuolaisia kokolihatuotteita tai eineksiä ei löytynyt. Mahdollisuutta merkitä tuote vähäsuolaiseksi oli käytetty vain noin puolessa niistä tuotteista joihin se olisi ollut mahdollista merkitä. Vähäsuolaisten tuotteiden valikoimissa ei ollut eroa neljän eri kaupan välillä. Kansanterveyden kannalta elintarviketeollisuuden tulisi lisätä vähäsuolaisten tuotteiden valikoimaa. Erityisesti olisi tarpeen kehittää vähäsuolaisia eineksiä. 
